\title{
Correction to Mühlberger et al. (2020)
}

In the article entitled "External valvuloplasty of the saphenofemoral junction in insufficient great saphenous veins - six weeks results of a prospective multicentre trial" by D. Mühlberger, E. Brenner, H. Brockhoff, N. Frings, B. Geier, A. Mumme, S. Reich-Schupke, A. L. Rohrer, H.-P. Steffen, D. Stenger, M. Stücker and T. Hummel (Vasa, 49, 411-417, https://doi.org/10.1024/0301-1526/a000874) the registry number of the ethical approval was given incorrectly on the second page of the print and PDF version. The correct registry number is 5034-14 instead of 5024-14.

The authors regret any inconvenience or confusion this error may have caused.

\section{Reference}

Mühlberger D, Brenner E, Brockhoff H, Frings N, Geier B, Mumme A, et al. External valvuloplasty of the saphenofemoral junction in insufficient great saphenous veins - six weeks results of a prospective multicentre trial. VASA. 2020;49(5):411-7. https:// doi.org/10.1024/0301-1526/a000874

Published online: 08.10.2021 